\title{
Oxidatively modified proteins in bronchoalveolar lavage fluid of patients with ARDS and patients at-risk for ARDS
}

\author{
A-G. Lenz ${ }^{\star}$, P.G. Jorens ${ }^{\star *}$, B. Meyer ${ }^{\star}$, W. De Backer ${ }^{+}$, F. Van Overveld ${ }^{+}$, L. Bossaert ${ }^{\star \star}$, K.L. Maier ${ }^{\star}$
}

Oxidatively modified proteins in bronchoalveolar lavage fluid of patients with ARDS and patients at-risk for ARDS. A-G. Lenz, P.G. Jorens, B. Meyer, W. De Backer, F. Van Overveld, L. Bossaert, K.L. Maier. C ERS Journals Ltd 1999.

ABSTRACT: Oxidative stress in acute respiratory distress syndrome (ARDS) is considered as an important pathophysiological mechanism in acute impairment of lung function. The present study investigated whether a pulmonary oxidant-antioxidant imbalance is indicated by substantial oxidative modification of proteins in bronchoalveolar lavage (BAL) fluid.

Oxidatively modified proteins in BAL fluid, as measured by the reduction of protein carbonyl groups with tritiated borohydride, were studied in control subjects, patients with clinically established ARDS, and patients considered at-risk for ARDS because they had had coronary bypass surgery. Subsets of these at-risk patients were pretreated either with methylprednisolone or $N$-acetylcysteine.

The carbonyl content of BAL fluid proteins was greatly increased in ARDS patients $\left(5.0 \pm 1.3 \mathrm{nmol}\right.$ carbonyl $\cdot \mathrm{mL}^{-1}$ BAL fluid; mean $\left.\pm \mathrm{sEM} ; \mathrm{p}=0.0004 ; \mathrm{n}=10\right)$ and moderately increased in the untreated patients at-risk for ARDS $\left(1.3 \pm 0.2 \mathrm{nmol} \cdot \mathrm{mL}^{-1} ; p=0.027\right.$; $\mathrm{n}=19)$ compared with controls $\left(0.8 \pm 0.2 \mathrm{nmol} \cdot \mathrm{mL}^{-1} ; \mathrm{n}=12\right)$. The two other at-risk groups pretreated either with methylprednisolone or $\mathrm{N}$-acetylcysteine showed carbonyl values that were statistically not different from the controls $\left(1.2 \pm 0.2 \mathrm{nmol} \cdot \mathrm{mL}^{-1} ; \mathrm{p}=0.13\right.$; $\mathrm{n}=13$, and $1.1 \pm 0.3 \mathrm{nmol} \cdot \mathrm{mL}^{-1} ; \mathrm{p}=0.40 ; \mathrm{n}=8$, respectively).

These results show that oxidatively modified proteins clearly accumulated in bronchoalveolar lavage fluid of acute respiratory distress syndrome patients, and to a minor extent in untreated at-risk patients. These data suggest a severe oxidantantioxidant imbalance in acute respiratory distress syndrome.

Eur Respir J 1999; 13: 169-174.

\author{
*GSF-Institute for Inhalation Biology, \\ D-85764 Neuherberg, Germany, **UZA- \\ Dept of Intensive Care and ${ }^{+}$Dept of \\ Respiratory Medicine, B-2650 Edegem, \\ Belgium
}

Correspondence: A-G. Lenz GSF-National Research Centre for Environment and Health

Institute for Inhalation Biology Ingolstaedter Landstr. 1

D-85764 Neuherberg/Munich

Germany

Fax: 498931873397

Keywords: acute respiratory distress syndrome

bronchoalveolar

lung injury

macrophages

neutrophils

oxidation

Received: September 11997

Accepted after revision September 31998
Many pulmonary diseases, including the acute respiratory distress syndrome (ARDS), chronic bronchitis/emphysema, asthma, and interstitial pulmonary fibrosis [1-3] have been associated with an excess of reactive oxygen species (ROS). Patients undergoing cardiopulmonary bypass (CPB) surgery have an elevated risk of developing ARDS [4] and also appear to be under oxidative stress [5]. In ARDS patients and patients at-risk for ARDS, the epithelial lining fluid (ELF) recovered as bronchoalveolar lavage (BAL) fluid is characterized by increased numbers of neutrophils [6] that are known to be potent in generating superoxide anions. BAL fluid of ARDS patients and at-risk patients contains a variety of cytokines [6, 7] as well as lipid mediators [8] that are known to prime or activate neutrophils for oxidant production. Substantial lack of the antioxidant glutathione (GSH) in the respiratory tract of ARDS patients as described by BUNNELL and PACHT [9] may enhance the risk for oxidant injury. The delicate balance between oxidant and antioxidant systems, however, is of major importance for maintaining normal lung function and structure. In the plasma of ARDS patients and patients at-risk for ARDS, oxidative stress was concluded from the formation of lipid peroxidation products $[5,10]$, and protein oxidation $[5,11]$. However, the situation in plasma does not necessarily reflect the situation in the lungs. So far it has not been shown that the presence of oxidants overwhelming the antioxidant defence capacities resulted in an oxidative modification of proteins in the lungs.

ROS, in particular the hydroxyl radical $(\cdot \mathrm{OH})$, which is formed in a Fenton-like reaction in the presence of free transition metal ions, are capable of reacting with most biological macromolecules such as lipids [12], proteins $[11,13]$, and nucleic acids [14]. Carbonyl formation in amino acid side chains of proteins is a major mechanism during oxidation, and quantification of these protein-bound carbonyls allows the determination of the extent of oxidative modification. The most important cause of ROSdependent modification of proteins is that mediated by metal-catalysed oxidation [13]. However, the oxidation need not occur directly on the protein. It can attack a lipid or carbohydrate, which produces a reactive intermediate that then reacts with the protein [13]. Normally, this pathophysiological reaction is minimized when redox-active metals such as iron remain tightly bound to storage and transport proteins including ferritin, transferrin, and lactoferrin. However, in ARDS, a distinct increase of the total iron content has been shown in ELF [15], which might support pro-oxidative mechanisms. In patients at-risk of 
developing ARDS serum ferritin levels were increased which may regulate the participation of iron in the oxidative responses [16].

This study examined whether an increased ROS production exceeding antioxidant defence capacities is reflected in an oxidative modification of proteins recovered from BAL fluid. We investigated whether the appearance of oxidatively modified BAL fluid proteins in patients with ARDS, and patients at-risk for ARDS was different from control subjects. The influence of treatment of at-risk patients either with methylprednisolone (MP) or $N$-acetylcysteine (NAC) on the recovery of oxidized proteins was further investigated.

\section{Methods}

In all cases, informed consent was obtained from the patients or their closest relatives in accordance with the revised Helsinki Declaration of 1983. The study protocol and procedure were approved by the ethical committee of the University Hospital of Antwerp.

\section{Study population}

Patients with ARDS. Ten nonsmoking patients (eight males, two females), aged 28-78 yrs (54 \pm 6 , mean \pm SEM) had established ARDS according to the classical criteria [4]: a history of a predisposing illness, sudden onset of dyspnoea, severe hypoxaemia, widespread diffuse lung infiltrates on chest radiographs without evidence of left ventricular failure (normal cardiothoracic index on chest radiography, no history of heart failure, a pulmonary capillary wedge pressure $<15 \mathrm{mmHg}$ ), and an arterial oxygen tension $\left(\mathrm{Pa}_{\mathrm{a}} \mathrm{O}_{2}\right) /$ inspiratory oxygen fraction $\left(F \mathrm{I}, \mathrm{O}_{2}\right)$ ratio $<200 \mathrm{mmHg}$. All patients underwent BAL within $12 \mathrm{~h}$ once the diagnosis of ARDS was established and their clinical status was stable enough (intubation, ventilation) to allow bronchoscopy and lavage. Predisposing factors were: $\mathrm{CPB}(\mathrm{n}=7)$, hypovolemic shock with excessive transfusion $(n=2)$ and postcardiac arrest coma $(n=1)$. Five of the ten patients died.

Patients at-risk for developing ARDS. Forty nonsmoking postcoronary bypass surgery patients (all males) underwent BAL $4 \mathrm{~h}$ after the end of the extracorporeal circulation. The pump-oxygenator system was primed with $1,800 \mathrm{~mL}$ crystalloid solution (Plasma-Lyle AR); (Baxter, Lessines, Belgium)) and $400 \mathrm{~mL}$ human albumin $20 \%$. None of the patients included in this group developed ARDS afterwards. None of them had a history of left ventricular failure (normal cardiothoracic index on chest radiography, no history of heart failure, pulmonary capillary wedge pressure $<15 \mathrm{mmHg}$ ). Nineteen male patients (aged 54-65 (60 \pm 2$)$ yrs) underwent standard CPB surgery; 13 male patients received $30 \mathrm{mg} \cdot \mathrm{kg}^{-1} \mathrm{me}-$

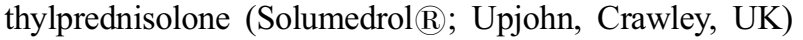
intravenously after induction of anaesthesia in an attempt to suppress BAL fluid signs of lung inflammation; 8 received $72 \mathrm{mg} \cdot \mathrm{kg}^{-1}$ NAC as a bolus, followed by 72 $\mathrm{mg} \cdot \mathrm{kg}^{-1}$ during $12 \mathrm{~h}$ preceding CPB in an attempt to restore intracellular glutathione levels and inhibit oxidative metabolism.

Bacterial cultures of both the initial bronchial aspirate and the BAL fluid were negative for all ARDS and post- surgical patients. At the time of BAL, all patients (ARDS and patients at-risk) were afebrile. The preoperative care, medication, general anaesthesia, priming solution, type of extracorporeal support system and postoperative care were standard in all patients and have been described previously $[6,17]$.

Controls. Twelve nonsmoking subjects (five males, seven females) aged $26-67$ yrs $(43 \pm 4$, mean \pm SEM) were referred to the outpatient clinic for elective bronchoscopy. The bronchial tree was macroscopically normal in all subjects at bronchoscopy. The cytology and culture of the BAL fluid were negative, as well as the subsequent clinical investigations (normal chest radiograph, normal spirometric results, normal lung volume). No major diseases were found, and the patients did not take any medication.

\section{Bronchoalveolar lavage}

ARDS and postsurgical patients were sedated and mechanically ventilated at the moment of the BAL. A flexible bronchoscope (Olympus, type P20D (New Hyde Park, NY, USA), outer diameter $5 \mathrm{~mm}$, inner diameter 2 $\mathrm{mm}$ ) was passed through the endotracheal tube of the ventilated patients after preoxygenation $\left(F \mathrm{I}, \mathrm{O}_{2}=1\right)$. In control subjects, bronchoscopy was performed by a standard procedure after premedication with diazepam/atropine and local anaesthesia with lidocaine. After wedging into the right middle lobe, three successive $50 \mathrm{~mL}$ aliquots of $0.9 \%$ saline were instilled and immediately aspirated. The aspirate of the first aliquot was discarded to prevent bronchial contamination and the recovered fluid of the second and third aliquots were pooled and kept at $4{ }^{\circ} \mathrm{C}$. Blood-tinged lavages were not used. After gauze filtration, the lavage fluid was immediately centrifuged at $500 \times g$ for $10 \mathrm{~min}$ and aliquots of the cell-free supernatant were stored at $-25^{\circ} \mathrm{C}$. The cells of the pellet were resuspended in $10 \mathrm{~mL}$ of Dulbecco's phosphate-buffered saline and counted with a Coulter counter. Cell differentiation was performed on cytospin preparations, which were stained using a modified Wright-Giemsa stain. A minimum of 300 cells were examined.

\section{Determination of protein-bound carbonyl groups}

BAL fluid supernatants were kept frozen at $-25^{\circ} \mathrm{C}$ until analysed. Protein-bound carbonyl groups in frozen samples are stable for at least two years (unpublished results). Frozen samples were thawed, dialysed for $3 \mathrm{~h}$ at $4{ }^{\circ} \mathrm{C}$ against $\mathrm{H}_{2} \mathrm{O}$, and aliquots of $1 \mathrm{~mL}$ freeze-dried in a vacuum centrifuge. Dried samples were redissolved in $50 \mu \mathrm{L} \mathrm{H}_{2} \mathrm{O}$, followed by the addition of $6 \mu \mathrm{L} 1 \mathrm{M}$ Tris-HCl$/ 10 \mathrm{mM}$ ethylenediaminetetraacetic acid (EDTA), $\mathrm{pH} 8.5$, and 14 $\mu \mathrm{L} 100 \mathrm{mM} \mathrm{NaB}^{3} \mathrm{H}_{4}$ in $0.1 \mathrm{M} \mathrm{NaOH}$ (specific activity, 3.7 $\mathrm{GBq} \cdot \mathrm{mmol}^{-1}$ ). After incubation at $37^{\circ} \mathrm{C}$ for $30 \mathrm{~min}$, the proteins were precipitated by $1 \mathrm{~mL} 10 \%$ trichloroacetic acid and centrifuged at $10,000 \times g$. Pellets were washed twice with $10 \%$ trichloroacetic acid, and redissolved in $70 \%$ formic acid for $45 \mathrm{~min}$ at $37^{\circ} \mathrm{C}$. The formic acid was then evaporated in a vacuum centrifuge. To remove tritium labels different from those in amino acids, the tritiated proteins were hydrolysed in $200 \mu \mathrm{L} 6 \mathrm{M} \mathrm{HCl}$ at $155^{\circ} \mathrm{C}$ for 
$60 \mathrm{~min}$. The hydrolysed samples were again evaporated to dryness and redissolved in $500 \mu \mathrm{L} 10 \mathrm{mM} \mathrm{HCl}$. Amino acids were separated from carbohydrates by chromatography of an aliquot of $450 \mu \mathrm{L}$ on a Dowex 50W-X8 column (BioRad, Munich, Germany) and eluted with $500 \mu \mathrm{L} 2 \mathrm{M}$ $\mathrm{NH}_{4} \mathrm{OH}$. The radioactivity in the $\mathrm{NH}_{4} \mathrm{OH}$ eluate was determined using a liquid scintillation counter. Each sample was assayed in duplicate or triplicate [18].

\section{Protein determination from the acid hydrolysates}

Protein concentration was estimated by amino acid determination in the remaining aliquot from the hydrolysed samples of $50 \mu \mathrm{L}$ using $o$-phthalaldehyde as previously described [18]. To convert the amino acid determination into an estimate of total protein, an average molecular weight of $110 \mathrm{Da}$ for amino acid residues, and of $50 \mathrm{kDa}$ for proteins was assumed. The carbonyl content of proteins was expressed as nmol carbonyl. $\mathrm{mL}^{-1}$ BAL fluid.

\section{Correction of the BAL fluid protein concentration for transudated plasma proteins}

To compensate for the considerable transudation of plasma proteins into the alveolar lumen in ARDS, the albumin content in BAL fluid was used as a marker of vascular permeability. It was assumed that the mean amount of albumin in the BAL fluid of controls is the amount that is normally present. The difference between this level and the level of albumin in individual patients was used to correct the BAL fluid protein content in ARDS patients according to the following equation:

$$
\begin{aligned}
& \text { Corrected protein }={ }^{\mathrm{P}} \text { Protein } \times\left(1-\left({ }^{\mathrm{P}}\right. \text { Albumin - }\right. \\
& { }^{\mathrm{C}} \text { Albumin) } /{ }^{\mathrm{P}} \text { Albumin)) }
\end{aligned}
$$

where $\mathrm{p}$ is individual patient value and $\mathrm{c}$ is mean in control.

\section{Oxidative injury index}

The oxidative injury index was defined as mol carbonyl.mol protein ${ }^{-1}$ assuming an average molecular weight of $50 \mathrm{kDa}$ for pulmonary proteins. For the calculation of the oxidative injury index the corrected values for BAL fluid proteins were used.

\section{Statistical analysis}

Statistical analysis was performed using the software package Statistical Analysis System (SAS) version 6.08 (SAS Institute, Cary, NC, USA). Results were expressed as the arithmetic mean \pm SEM. To indicate differences between the various groups the data were submitted to the Wilcoxon rank-sum test. Differences with $\mathrm{p}<0.05$ were considered significant. Correlation factors were calculated using the Spearman rank order coefficient.

\section{Results}

BAL fluid data for all patient groups are summarized in tables 1 and 2. Fluid recovery was the same in all groups, with the exception of the at-risk patient group pretreated with NAC and the ARDS group, who showed a slightly increased recovery compared with the controls $(\mathrm{p}=0.011$ and $\mathrm{p}=0.05$, respectively) (table 1 ).

The total number of BAL fluid cells obtained from the ARDS patients was increased $(p=0.029)$ compared with the controls, largely due to the increase in neutrophil numbers (table 1). Neutrophils dramatically increased in this group as compared with the controls $(\mathrm{p}=0.001)$, reaching values of up to $82 \%$ of total cell numbers. Total cell numbers were unchanged in the three at-risk patient groups. However moderate increases in neutrophil numbers were seen in untreated $(\mathrm{p}=0.025)$ or MP-treated $(\mathrm{p}=0.025)$ atrisk patients, whereas in the NAC-treated at-risk patients values were not different from the controls $(\mathrm{p}=0.43)$.

The mean albumin concentration in the control patients was $36 \mu \mathrm{g} \cdot \mathrm{mL}^{-1}$ (table 2). A moderate increase of this parameter was found in the untreated at-risk patient group $(p=0.010)$, while a 6-fold increase was observed in ARDS patients $(\mathrm{p}=0.0002)$ compared with controls. In parallel, total protein was 2.4-fold increased in the untreated at-risk group ( $\mathrm{p}=0.0001$ ), and most clearly in the ARDS group showing a nine-fold increase versus controls $(\mathrm{p}=0.0001)$. Total protein was also increased in the MP-treated $(\mathrm{p}=$ $0.021)$ and in the NAC-treated at-risk groups $(\mathrm{p}=0.018)$.

The amount of oxidized proteins, expressed as nmol carbonyl.mL BAL fluid ${ }^{-1}$, was increased in untreated patients at-risk for ARDS ( $\mathrm{p}=0.027)$, and markedly increased in patients with ARDS ( $\mathrm{p}=0.0004)$ (fig. 1 and table 2$)$. The levels of oxidized proteins in the ARDS patients exceeded the mean concentration of the control group by two standard deviations in seven of ten patients.

\begin{tabular}{|c|c|c|c|c|c|}
\hline $\begin{array}{l}\text { BAL fluid } \\
\text { parameters }\end{array}$ & $\begin{array}{l}\text { Control } \\
(\mathrm{n}=12)\end{array}$ & $\begin{array}{c}\text { At-risk for } \\
\text { ARDS untreated } \\
(\mathrm{n}=19)\end{array}$ & $\begin{array}{c}\text { At-risk for } \\
\text { ARDS MP-treated } \\
(\mathrm{n}=13)\end{array}$ & $\begin{array}{l}\text { At-risk for } \\
\text { ARDS NAC-treated } \\
(\mathrm{n}=8)\end{array}$ & $\begin{array}{l}\text { ARDS } \\
(n=10)\end{array}$ \\
\hline Fluid recovery $\mathrm{mL}$ & $\begin{array}{c}42 \pm 5 \\
(25-90)\end{array}$ & $\begin{array}{c}47 \pm 4 \\
(23-74)\end{array}$ & $\begin{array}{c}45 \pm 4 \\
(25-70)\end{array}$ & $\begin{array}{c}63 \pm 6^{*} \\
(30-80)\end{array}$ & $\begin{array}{r}54 \pm 6^{*} \\
(25-90)\end{array}$ \\
\hline Total cells $\times 10^{3} \cdot \mathrm{mL}^{-1}$ & $\begin{array}{r}186 \pm 34 \\
(67-430)\end{array}$ & $\begin{array}{c}231 \pm 37 \\
(17-512)\end{array}$ & $\begin{array}{c}148 \pm 32 \\
(69-507)\end{array}$ & $\begin{array}{c}141 \pm 65 \\
(10-518)\end{array}$ & $\begin{array}{c}411 \pm 90^{*} \\
(147-1067)\end{array}$ \\
\hline Macrophages \% & $\begin{array}{c}91 \pm 2 \\
(81-98)\end{array}$ & $\begin{array}{c}86 \pm 3 \\
(63-99)\end{array}$ & $\begin{array}{c}82 \pm 3^{*} \\
(55-96)\end{array}$ & $\begin{array}{c}89 \pm 2 \\
(78-99)\end{array}$ & $\begin{array}{c}47 \pm 7^{+} \\
(32-63)\end{array}$ \\
\hline Neutrophils \% & $\begin{array}{c}1.5 \pm 0.5 \\
(0.01-6)\end{array}$ & $\begin{array}{c}6 \pm 2 * \\
(1-34)\end{array}$ & $\begin{array}{c}5 \pm 1^{*} \\
(0.01-18)\end{array}$ & $\begin{array}{r}2.4 \pm 0.9 \\
(0.01-7)\end{array}$ & $\begin{array}{l}49 \pm 8^{+} \\
(6-82)\end{array}$ \\
\hline
\end{tabular}

Table 1. - Total and differential cell counts in bronchoalveolar lavage (BAL) fluid

Values represent mean \pm SEM with ranges shown in parentheses. ${ }^{*}: \mathrm{p}<0.05,{ }^{+}: \mathrm{p}>0.005, \mathrm{p}$-values for comparisons with control group. ARDS: acute respiratory distress syndrome; MP: methylprednisolone; NAC: $N$-acetylcysteine. 
Table 2. - Protein content of bronchoalveolar lavage (BAL) fluid and oxidative status of proteins

\begin{tabular}{|c|c|c|c|c|c|}
\hline $\begin{array}{l}\text { BAL fluid } \\
\text { parameters }\end{array}$ & $\begin{array}{l}\text { Control } \\
(n=12)\end{array}$ & $\begin{array}{c}\text { At-risk for } \\
\text { ARDS untreated } \\
(\mathrm{n}=19)\end{array}$ & $\begin{array}{c}\text { At-risk for } \\
\text { ARDS MP-treated } \\
(\mathrm{n}=13)\end{array}$ & $\begin{array}{c}\text { At-risk for } \\
\text { ARDS NAC-treated } \\
(\mathrm{n}=8)\end{array}$ & $\begin{array}{l}\text { ARDS } \\
(\mathrm{n}=10)\end{array}$ \\
\hline Albumin $\mu \mathrm{g} \cdot \mathrm{mL}^{-1}$ & $\begin{array}{r}36 \pm 7 \\
(9-91)\end{array}$ & $\begin{array}{c}57 \pm 6^{+} \\
(19-94)^{\#}\end{array}$ & $\begin{array}{c}60 \pm 13 \\
(10-202)\end{array}$ & $\mathrm{ND}$ & $\begin{array}{c}292 \pm 80^{+} \\
(82-761)^{+}\end{array}$ \\
\hline Total protein $\mu \mathrm{g} \cdot \mathrm{mL}^{-1}$ & $\begin{array}{c}55 \pm 9 \\
(23-135)\end{array}$ & $\begin{array}{l}130 \pm 19^{+} \\
(46-370)\end{array}$ & $\begin{array}{r}107 \pm 22 * \\
(43-335)\end{array}$ & $\begin{array}{c}156 \pm 63^{*} \\
(27-591)\end{array}$ & $\begin{array}{c}515 \pm 158^{+} \\
(104-1644)\end{array}$ \\
\hline Carbonyl nmol $\cdot \mathrm{mL}^{-1}$ & $\begin{array}{c}0.8 \pm 0.2 \\
(0.2-2.4)\end{array}$ & $\begin{array}{c}1.3 \pm 0.2^{*} \\
(0.4-3.4)\end{array}$ & $\begin{array}{r}1.2 \pm 0.2 \\
(0.4-3.7)\end{array}$ & $\begin{array}{r}1.1 \pm 0.3 \\
(0.2-3.2)\end{array}$ & $\begin{array}{l}5.1 \pm 1.3^{+} \\
(1-12.6)\end{array}$ \\
\hline Carbonyl nmol $\cdot \mathrm{mg}^{-1}$ & $\begin{array}{c}14.1 \pm 1.6 \\
(6.4-23.3)\end{array}$ & $\begin{array}{c}11.0 \pm 1.5 \\
(4.4-26.9)\end{array}$ & $\begin{array}{c}13.3 \pm 2.1 \\
(5.4-32.9)\end{array}$ & $\begin{array}{c}8.1 \pm 0.9^{*} \\
(3.9-11.4)\end{array}$ & $\begin{array}{r}11.2 \pm 1.6 \\
(5.3-22.9)\end{array}$ \\
\hline Carbonyl mol.mol CP & $\begin{array}{c}0.7 \pm 0.2 \\
(0.1-2.2)\end{array}$ & $\begin{array}{c}1.0 \pm 0.1 \\
(0.4-1.9)^{\#}\end{array}$ & $\begin{array}{c}1.0 \pm 0.2 \\
(0.3-2.7)\end{array}$ & $\mathrm{ND}$ & $\begin{array}{c}4.0 \pm 0.9^{+} \\
(1.1-9.1)^{\$} \\
\end{array}$ \\
\hline
\end{tabular}

Values represent mean \pm SEM with ranges shown in parentheses. ${ }^{*}: \mathrm{p}<0.05,{ }^{+}: \mathrm{p}>0.005, \mathrm{p}$-values for comparisons with control group. ${ }^{\#}$ : mean calculated from $n=13 ; \$$ : mean calculated from $n=9$. For abbreviations see legend to table 1. ND: not determined; CP: corrected protein according to the following equation, $\mathrm{CP}={ }^{\mathrm{P}}$ Protein $\times\left(1-\left({ }^{\mathrm{P}}\right.\right.$ Albumin $-{ }^{\mathrm{C}}$ Albumin $){ }^{\mathrm{P}}$ Albumin $\left.)\right)$ where $\mathrm{p}$ is patient value and $\mathrm{c}$ is mean in control.

The data in the two pretreated at-risk groups indicated values that were both about 1.5 -fold increased but statistically the same as the controls $(p=0.13$ for MPtreatment, and $\mathrm{p}=0.40$ for NAC-treatment). The box plot (fig. 1) shows that the medians for oxidized proteins in the three at-risk patient groups were very close together, that the median in the ARDS group was distinctly above them, and that the median for the control group was well below the others. Oxidized protein values appeared to vary somewhat more in the untreated at-risk patients, and much more in ARDS patients than in the control with a larger central box and longer "whiskers". In the ARDS group, the data showed a nongaussian distribution, skewed to higher values. When carbonyl values were related to the protein content (nmol carbonyl.mg protein ${ }^{-1}$ ) there were no significant differences between groups, only the NACtreated at-risk patients showed decreased values compared

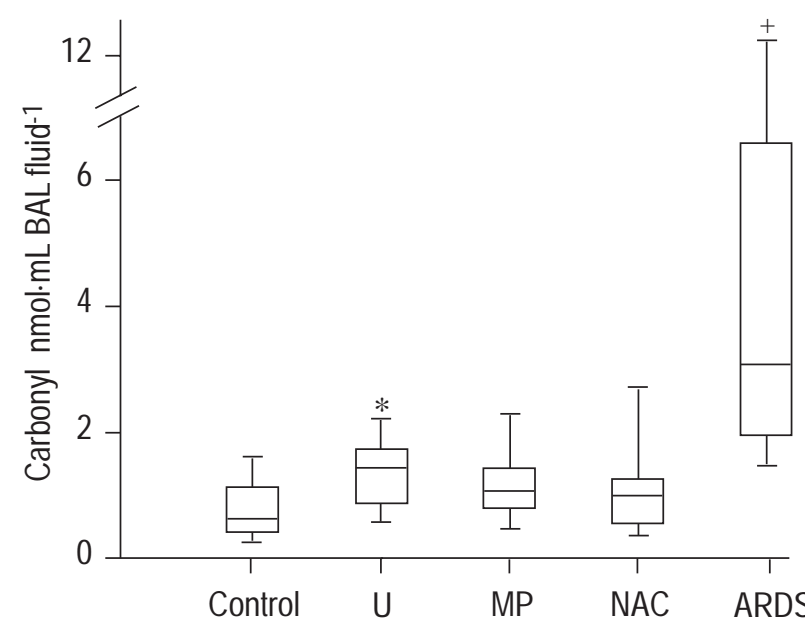

Fig. 1. - Box plot of protein-bound carbonyl groups in bronchoalveolar lavage (BAL) fluid of controls $(n=12)$, untreated (U) patients at-risk for acute respiratory distress syndrome (ARDS) $(n=19)$, methylprednisolone (MP)-treated patients at-risk for ARDS $(\mathrm{n}=13), N$-acetylcysteine (NAC)treated patients at-risk for ARDS $(\mathrm{n}=8)$, and patients with ARDS $(\mathrm{n}=10)$. The box covers the middle $50 \%$ of the data values, between the lower and upper quartile. The whiskers extend out to the extremes (minimum and maximum values) that are within the interquartile range, whilst the central line is the median. ${ }^{*}: \mathrm{p}<0.05,{ }^{+}: \mathrm{p}<0.005$, $\mathrm{p}$-values for comparisons with control group. with controls $(\mathrm{p}=0.049)$ (table 2$)$. In order to evaluate the severity of oxidative modification on a single protein level, an oxidative injury index was defined indicating the number of modified sites per molecule. The oxidative injury index ( $\mathrm{mol} \mathrm{carbonyl} \cdot \mathrm{mol}$ corrected protein ${ }^{-1}$ ) revealed that a protein with an average size of $50 \mathrm{kDa}$ in the control group carried less than one oxidative hit, while a protein in patients with ARDS carried up to four oxidative hits $(\mathrm{p}=0.0006)$ (table 2).

Correlations of oxidized proteins (nmol carbonyl.ml BAL fluid ${ }^{-1}$ ) with inflammatory parameters showed an association with absolute and relative numbers of neutrophils $(\mathrm{r}=0.4, \mathrm{p}=0.01$ and $\mathrm{r}=0.36, \mathrm{p}=0.04$, respectively) taking all groups together. Within single groups no correlations were found.

\section{Discussion}

The current study has shown that the oxidant-antioxidant balance was markedly disturbed in the lungs of patients with established ARDS, and untreated patients atrisk for ARDS, as noted by an increase in oxidatively modified proteins in BAL fluid. Thus, the proteins in ELF represent a major target for unbalanced ROS produced in the lungs. It is not only lipid peroxidation with membrane damage [12] or chain breaks in nucleic acids [14] that are caused by metal-catalysed oxidation, but also injuries of structural and functional proteins [13]. The reported finding that oxidative modification of proteins is an early event in oxidative damage to endothelial cells suggests that oxidative modification of proteins is not only a marker for oxidative stress but a causal factor in oxidative injury [19]. On the basis of these results, it is proposed that oxidized species of pulmonary proteins may be important in the pathogenesis of ARDS.

Protein-bound carbonyl can be expressed as carbonyl.mL BAL fluid ${ }^{-1}$, or carbonyl.mg BAL fluid protein ${ }^{-1}$. Normalization of carbonyl to volume as the denominator is useful when the BAL fluid recovery is reproducible and not substantially altered by an underlying disease. In diseases associated with an increased transudation rate of plasma proteins into the alveolar lumen, oxidized species of plasma proteins may contribute to the total amount of protein-bound carbonyl groups in BAL fluid. QUINLAN et al. [11] had shown an increased, but still very low extent of 
oxidation in plasma proteins of ARDS patients, we therefore think that this contribution is also low. At extensive transudation of plasma proteins the oxidative burden of the lungs can be obscured by normalization of carbonyl to BAL fluid protein (carbonyl.mg protein $^{-1}$ ). This is particularly important in BAL fluid samples from ARDS patients and patients at-risk for ARDS with high albumin levels, indicating an enhanced permeability of the alveolocapillary membrane for plasma proteins. In these cases, analysis of carbonyl content.mg BAL fluid protein ${ }^{-1}$ would result in an underestimation of the total lung content of oxidized proteins. In an attempt to compensate for transudation of plasma proteins into the alveolar compartment, albumin was used as a marker for permeability and total BAL fluid protein values were corrected. An oxidative injury index was then calculated for pulmonary proteins (mol carbonyl.mol corrected BAL fluid protein ${ }^{-1}$ ) indicating the number of modified sites per protein molecule.

The level of oxidatively modified proteins in ELF measured as protein-carbonyl derivatives is determined by several mechanisms that are provided in the respiratory tract: 1) Oxidative modification of pulmonary proteins is influenced by the oxidant-antioxidant balance. Several antioxidant systems are available [20] to protect the lung from increased endogenous or exogenous oxidant burden. As shown by BunNELL and PACHT [9] ELF of ARDS patients is deficient in reduced GSH as one of the major antioxidants. 2) The availability of catalytic transition metal ions acting as pro-oxidants is another regulative mechanism involved in the generation of carbonyl groups in proteins. In regions of tissue inflammation, disrupted cells release iron from ferritin [21], which is then available for the Fenton reaction. The total iron content of BAL fluid from ARDS patients was distinctly higher than that from controls [15] which may, together with the decrease in GSH [9], enhance the risk for oxidative modification of proteins. 3) Oxidation of proteins renders them highly susceptible to proteolytic degradation, thus accelerating their turnover rate [13]. This mechanism limits the accumulation of oxidatively modified proteins.

The oxidative status of the BAL fluid proteins, defined as nmol carbonyl.mL BAL fluid ${ }^{-1}$, was distinctly elevated in ARDS patients. Further, the oxidative injury index indicating the extent of the oxidative modification of proteins on a $\mathrm{mol} / \mathrm{mol}$ basis revealed that ARDS patients incurred, on average, five times the level of oxidation of the proteins of control subjects. These results indicate the presence of considerable amounts of unbalanced oxidants and suggest that BAL fluid proteins in ARDS are functionally altered, either activated or crippled. Consequently, relevant systems and functions in the respiratory tract such as the protease-antiprotease balance, surfactant, or mucus may become dysfunctional. The observation that interleukin (IL)- 8 was increased in the BAL fluid of ARDS patients [6] is consistent with the high neutrophil numbers found in the BAL fluid of these patients. Acute lung injury in ARDS is thought to be largely due to activated neutrophils, which not only aggravate oxidative stress in the lungs but also release mediators, including cytokines [7] and lipids [8]. Taking all groups together, the amount of protein carbonyl derivatives correlated with absolute and relative neutrophil levels, suggesting an important role of neutrophils in this oxidation process. Currently there is no direct evidence as to which type of antioxidant may play a role in controlling the levels of protein-carbonyl derivatives in the lungs. Although transferrin and ceruloplasmin may have potential in inhibiting lipid peroxidation [22] the increased levels in BAL fluid of ARDS patients did or did not completely prevent carbonyl formation in BAL fluid proteins.

CPB surgery patients have an elevated risk for ARDS [4]. The use of extracorporeal circulation during surgery induces activation of complement which promotes neutrophils to adhere and aggregate [23], resulting in neutrophil influx into the lungs. Pulmonary dysfunction caused by pulmonary neutrophil sequestration is a known postoperative complication in these patients. It has been reported that CPB surgery imposes an oxidative burden in plasma [5]. In this study population, the concentrations of neutrophils, albumin, and total protein were increased in BAL fluid of untreated $\mathrm{CPB}$ patients compared with controls, although to a much lower extent than in ARDS patients. Proteincarbonyl derivatives were significantly higher in these patients than in controls, suggesting an increased oxidative burden in their lungs. Patients undergoing bypass surgery are subject to haemodilution during operation. The effect of haemodilution on BAL fluid parameters has not been studied. Although the BAL was performed $4 \mathrm{~h}$ after the end of the procedure, it cannot be excluded that haemodilution might have influenced BAL fluid parameters. Since albumin was present in the haemodilution liquid, this component was stable in plasma, as well as in ELF.

Glucocorticoids are used in different departments of cardiac surgery with the intention of preventing the systemic inflammatory response encountered during bypass surgery [17]. It has been reported that glucocorticoids reduce neutrophil counts in BAL fluid [24]. We therefore pretreated at-risk patients with MP to suppress potential deleterious effects of activated neutrophils in the lungs. However, in our study this pretreatment did not prevent pulmonary neutrophil infiltration. It also did not prevent the increase in protein and albumin in BAL fluid, as a marker of the integrity of the alveolocapillary membrane. Levels of oxidized proteins, which were significantly increased in the untreated at-risk patients, showed a tendency to elevated values in MP-treated at-risk patients but were statistically not different from controls.

The thiol-containing antioxidant NAC has been used for systemic treatment of respiratory diseases [25]. It appears to act as a scavenger of ROS either directly or by raising intracellular concentrations of cysteine, and hence of GSH. NAC had been used to assess its potential role to interfere with neutrophil-mediated inflammation and lung injury, in particular to prevent oxidative processes. In this study, a high-dose pretreatment of CPB surgery patients did not affect the levels of protein-carbonyl groups compared with control subjects, although values were slightly increased and similar to those in the untreated at-risk group. The observed increase in BAL fluid protein in untreated at-risk patients was also observed in the NAC-treated at-risk patients, whereas the relative number of neutrophils was not different from the controls.

The oxidation of proteins present in the ELF may be important in the pathogenesis of ARDS, since oxidation of structural and functional proteins often affects their normal function $[13,26]$. Oxidized proteins are likely to be key regulatory factors for cytokine production $[27,28]$. Activation of the transcription nuclear factor (NF)- $\mathrm{BB}$ by 
redox changes [28] enhances release of IL-8, one of the strongest chemoattractants for neutrophils. Similarly, recent studies have shown that oxidants may directly induce release of chemokines from lung cells [27]. An important enzyme system in the pathogenesis of ARDS may be phospholipase $\mathrm{A}_{2}\left(\mathrm{PLA}_{2}\right)$ which is increased in BAL fluid of ARDS patients [29]. It is activated by phosphorylation and releases precursors for production of phospholipid mediators. ROS are involved in the activation mainly by inhibiting tyrosine protein phosphatase activity, which causes inactivation of $\mathrm{PLA}_{2}$ by dephosphorylation [26]. This may result in increased levels of phospholipids in BAL fluid. The presence of these phospholipids may substantially enhance the permeability of the alveolocapillary membrane [30] and favour lung oedema.

In conclusion, coronary bypass surgery with the risk of development of acute respiratory distress syndrome and established acute respiratory distress syndrome were associated with the presence of oxidatively modified proteins in bronchoalveolar lavage fluid, some of which are probably of pulmonary origin. It is proposed that the modulation of important protein functions by oxidation may be part of the pathophysiological events encountered in acute respiratory distress syndrome.

\section{References}

1. Repine JE. Scientific perspectives on adult respiratory distress syndrome. Lancet 1992; 339: 466-469.

2. Barnes PJ. Reactive oxygen species and airway inflammation. Free Rad Biol Med 1990; 9: 235-243.

3. Crystal RG. Oxidants and respiratory tract epithelial injury: pathogenesis and strategies for therapeutic intervention. Am J Med 1991; 91: 2-39.

4. Bernard GR, Artigas A, Brigham KL, et al. The American-European Consensus Conference on ARDS. Definitions, mechanisms, relevant outcomes, and clinical trial coordination. Am J Respir Crit Care Med 1994; 149: 818-824.

5. Pepper JR, Mumby S, Gutteridge JMC. Sequential oxidative damage, and changes in iron-binding and iron oxidising plasma antioxidants during cardiopulmonary bypass surgery. Free Rad Res 1994; 21: 377-385.

6. Jorens PG, Van Damme J, De Backer W, et al. Interleukin 8 (IL-8) in the bronchoalveolar lavage fluid from patients with the adult respiratory distress syndrome (ARDS) and patients at risk for ARDS. Cytokine 1992; 4: 592-597.

7. Jorens PG, Bossaert LL. Cytokine-networks and ARDS. In: Vincent JL, ed. Yearbook of Intensive Care and Emergency Medicine. Springer-Verlag, Berlin 1997; pp. 83-90.

8. Bernard GR, Korley V, Chee P, Swindell B, Ford-Hutchinson AW, Tagari P. Persistent generation of peptido leukotrienes in patients with adult respiratory distress syndrome. Am Rev Respir Dis 1991; 144: 263-267.

9. Bunnell E, Pacht ER. Oxidized glutathione is increased in the alveolar fluid of patients with the adult respiratory distress syndrome. Am Rev Respir Dis 1993; 148: 11741178.

10. Richard C, Lemonnier F, Thibault M, Couturie M, Auzopy P. Vitamin E deficiency and lipid peroxidation during adult respiratory distress syndrome. Crit Care Med 1990; 18: 4-6.

11. Quinlan GJ, Evans TW, Gutteridge JMC. Oxidative damage to plasma proteins in adult respiratory distress syndrome. Free Rad Res 1994; 20: 289-298.
12. Halliwell B, Gutteridge JMC. Lipid peroxidation, oxygen radicals, cell damage and antioxidant therapy. Lancet 1984; 1: 1396-1398.

13. Levine RL, Stadtman ER. Protein modifications with aging. In: Schneider EL, Rowe JW, eds. Handbook of the Biology of Aging. San Diego, Academic Press, 1996; pp. 184-197.

14. Halliwell B, Auroma OI. DNA damage by oxygen-derived species: its mechanism and measurement in mammalian systems. FEBS Lett 1991; 281: 9-19.

15. Gutteridge JMC, Mumby S, Quinlan GJ, Chung KF, Evans TW. Pro-oxidant iron is present in human pulmonary epithelial lining fluid: implications for oxidative stress in the lung. Biochem Biophys Res Comm 1996; 220 : 1024-1027.

16. Connelly KG, Moss M, Parsons PE, et al. Serum ferritin as a predictor of the acute respiratory distress syndrome. Am J Respir Crit Care Med 1997; 155: 21-25.

17. Jorens PG, De Jongh R, De Backer W, et al. Interleukin-8 production in patients undergoing cardiopulmonary bypass. The influence of pretreatment with methylprednisolone. Am Rev Respir Dis 1993; 148: 890-895.

18. Lenz A-G, Costabel U, Shaltiel S, Levine RL. Determination of carbonyl groups in oxidatively modified proteins. Anal Biochem 1988; 177: 419-425.

19. Ciolono HP, Levine RL. Modification of proteins in endothelial cell death during oxidative stress. Free Rad Biol Med 1997; 22: 1277-1282.

20. Maier KL. How the lung deals with oxidants. Eur Respir $J$ 1993; 6: 334-336.

21. Halliwell B, Gutteridge JMC. Oxygen toxicity, oxygen radicals, transition metals and disease. Biochem J 1984; 219: 1-14.

22. Lykens MG, Davis WB, Pacht ER. Antioxidant activity of bronchoalveolar lavage fluid in the adult respiratory distress syndrome. Am J Physiol 1992; 262: L169-L175.

23. Antonsen S, Brandslund I, Clemensen S, Sofeldt S, Madsen T, Alstrup P. Neutrophil lysosomal enzyme release and complement activation during cardiopulmonary bypass. Scand J Thorac Cardiovasc Surg 1987; 21: 4752.

24. Fosse E, Mollnes TE, Osterud A, Aasen AO. Effects of methylprednisolone on complement activation and leucocyte counts during cardiopulmonary bypass. Scand $J$ Thorac Cardiovasc Surg 1987; 21: 255-261.

25. Meyer A, Buhl R, Kampf S, Magnussen H. Intravenous $\mathrm{N}$-acetylcysteine and lung glutathione of patients with pulmonary fibrosis and normals. Am J Respir Crit Care Med 1995; 152: 1055-1060.

26. Goldman R, Ferber E, Zort U. Reactive oxygen species are involved in the activation of cellular phospholipase A2. FEBS Lett 1992; 309: 190-192.

27. Shi MM, Godleski JJ, Paulauskis JD. Regulation of macrophage inflammatory protein- $1 \alpha$ mRNA by oxidative stress. J Biol Chem 1996; 271: 5878-5883.

28. Meyer M, Pahl HL, Baeuerle PA. Regulation of the transcription factors NF-kappa B and AP-1 by redox changes. Chem Biol Interact 1994; 91: 91-100.

29. Kim DK, Fukuda T, Thompson BT, Cockrill B, Hales C, Bonventre JV. Bronchoalveolar lavage fluid phospholipase A2 activities are increased in human adult respiratory distress syndrome. Am J Physiol 1995; 269: 109118.

30. Longphre M, Kleeberger SR. Susceptibility to plateletactivating factor-induced airway hyperreactibility and hyperpermeability: interstrain variation and genetic control. Am J Respir Cell Mol Biol 1995; 13: 586-594. 